\title{
Names of researchers who commit fraud may be disclosed
}

$\mathrm{T}$ he Canadian panel that promotes and oversees research integrity is considering increasing transparency by publishing - or having the relevant funding agency disclose - the names and institutional affiliations of researchers who commit serious breaches of ethics.

The Panel on Responsible Conduct of Research, launched in December 2011 by Canada's three major granting agencies, reviews the findings of an institution's investigation into allegations of scientific misconduct, data falsification, plagiarism or misuse of funds. The panel does not conduct its own investigations, but if a researcher breaches policies, he or she can be denied any further federal funding.

Previously, the panel withheld names to comply with the federal Privacy Act, says Marc Joanisse, panel chair and a psychology professor at Western University in London, Ontario, but that protection is about to end.

Researchers who apply for funding from the Canadian Institutes of Health Research (CIHR), the Natural Sciences and Engineering Research Council of Canada or the Social Sciences and Humanities Research Council (collectively known as the Tri-Council) must now check a box on the Consent to Disclosure of Personal Information Policy forms agreeing that if they are ever found in breach of the ethics regulations, their names may be released. This will give both their funding agencies and the panel the ability to release names, Joanisse says.

"We will probably be seeing those files soon where, once a fairly egregious case comes through, it will be easy for a Tri-Council president to release names," Joanisse says. "I would like it that way."

But publishing these breaches has so far been left to the agency presidents' discretion, and researchers' names are often only unearthed through Access to Information requests.

The panel's American counterpart, The Office of Research Integrity (ORI), has automatic disclosure.

The panel and the Secretariat on Responsible Conduct of Research, the federal body that administers the panel, have a mandate very similar to the

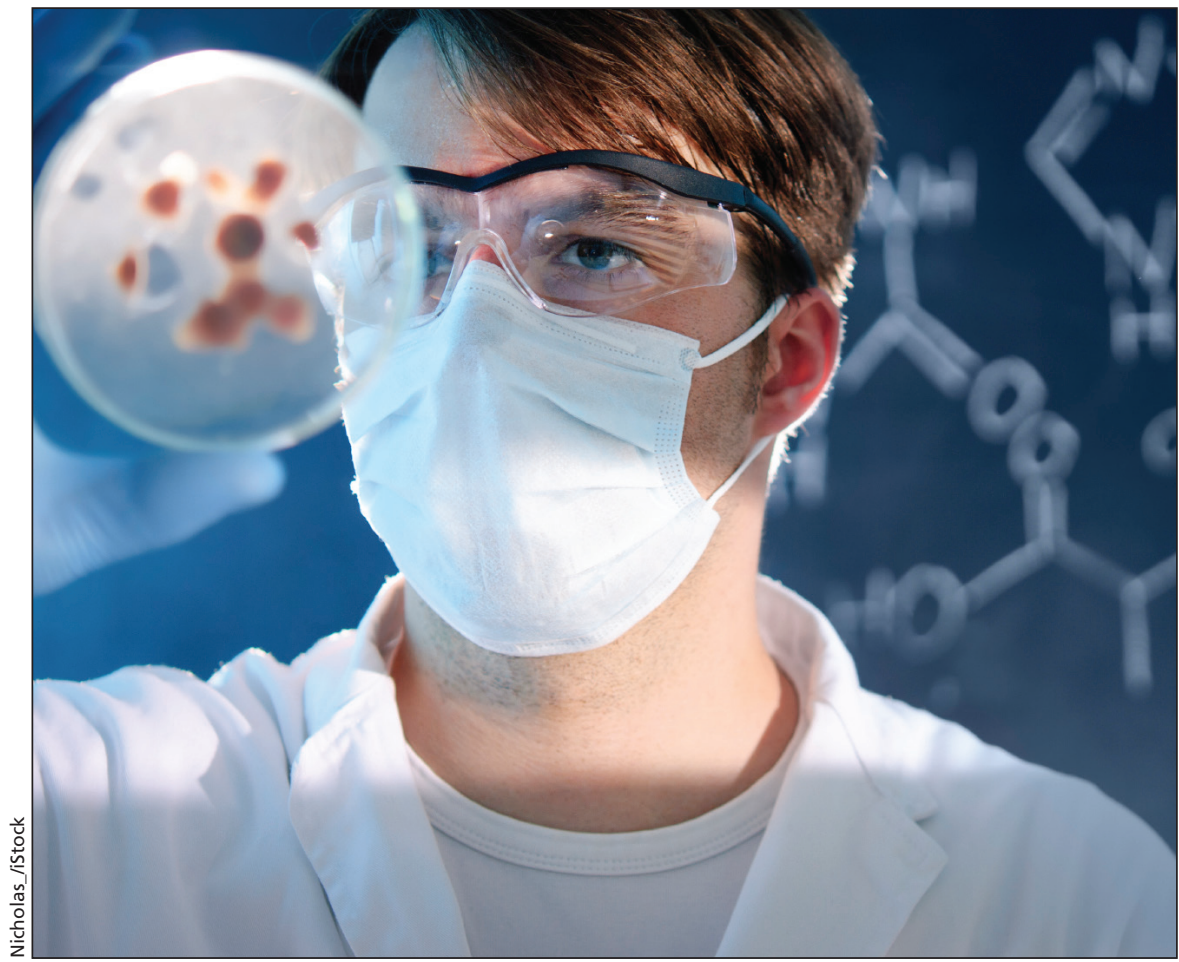

Researchers who receive federal funding must agree to have their names released if they breach ethics regulations.

ORI, wrote Susan Zimmerman, the Secretariat's executive director, in an email. (She did not respond to requests for a verbal interview.)

"While both bodies engage in implementation of standards of conduct by researchers, the Canadian Tri-Agency Framework: Responsible Conduct of Research covers a much broader range of conduct than the narrow US focus on misconduct, and specifically, fabrication, falsification and plagiarism," Zimmerman wrote.

\section{Transparency differences}

There is a substantial difference in transparency, however. When the ORI finishes a review, it publishes the name and the institution of the researcher or researchers involved, and issues a news release as well as case summaries online.

The Canadian panel, by contrast, simply issues reports containing anonymized statistics indicating how many files it "addressed," how many it closed and how many it upheld.

In the 2014/15 fiscal year, for example, the panel reviewed 89 files. It closed
42, of which 14 involved confirmed breaches of Tri-Council research ethics policy - including seven instances of plagiarism - and 28 files were not upheld. That left 45 cases still active at the beginning of $2015 / 16$, according to CIHR's website. The breaches involved "plagiarism, falsification of data, breach of agency guidelines, mismanagement of agency funds and misrepresentation in an agency application or related document," states the panel's report.

The ORI receives 350-450 allegations of research misconduct annually, but most of them don't fall within the definitions of the legislation governing the organization, are frivolous or involve research that isn't funded by the National Institutes of Health. Only 30-40 cases go through an oversight review; the ORI makes misconduct findings in about $10-15$ cases annually. All the names are released.

The thorny issue of protecting individual privacy over taxpayers' right to know how public money is being misspent has given rise to the blog Retraction Watch. Founded by two veteran US science journalists, it tracks retrac- 
tions issued by journals and other scientific publications around the world, and investigates and publishes the stories behind the retractions.

The use of public money to finance research demands accountability in Canada as in the United States and elsewhere, says Retraction Watch cofounder Ivan Oransky. He believes the names of those falsifying data or misspending public money should be publicized. "I don't really see any reasonable argument for withholding those names and keeping those things anonymous."

An international registry of disgraced researchers would also be a good idea, says Oransky, given that researchers can easily move to another institution. In the absence of transparency, it's difficult for an institution to check the researcher's record.

A case in point, says Oransky, is Fawzi Razem, a former University of Manitoba plant science researcher whom the university sanctioned in 2009 for falsifying data published in Nature. Razem subsequently moved to the Palestine Polytechnic University where he joined the faculty as Fawzi Alrazem. something bad it could appear in the media. I don't have any issue with that," he says.

That's a point Glavin makes when educating undergraduate, graduate and

\section{An international registry of disgraced researchers would be a good idea.}

“Shouldn't you know if you are a future employer or a future granting agency, that this person has committed misconduct?" asks Oransky.

If the Canadian panel decides to publish the names of researchers who have falsified data or conducted other breaches of ethics regulations, the institutions they work for may not be happy - but they will understand the decision, says Gary Glavin, associate vice president (research) at the University of Manitoba.

"You know full well that if you do postdoctoral students and faculty. After the Razem case, the university began offering a course as part of its ongoing efforts to promote responsible research, Glavin says. Other Canadian universities have followed suit.

"Based on our experience, the system is working," says Glavin. "We're policing ourselves and we're doing it very well. Students and faculty are clearly getting it. I believe universities are getting it." - Laura Eggertson, Ottawa

CMAJ 2015. DOI:10.1503/cmaj.109-5146 